\title{
MENGUKUR KEKUATAN ALAT BUKTI ELEKTRONIK DALAM PEMBUKTIAN PERKARA TINDAK PIDANA KORUPSI
}

\section{Supardi}

Universitas Pembangunan Nasional (UPN) Veteran Jakarta, Indonesia

Email: supardi@upnvj.ac.id

\section{Abstract}

One of the negative impacts of the advancement of digital technology is the growth of various crimes using electronic means or other means based on computerization, no exception to corruption. The situation requires law enforcement officials in proving the crime of corruption not only rely on conventional evidence, but combine electronic digital technology methods so as to give birth to electronic evidence. The fundamental issues related to this in Indonesia are: (1) How is the regulation of electronic evidence in Indonesian law (2) How is the position of electronic evidence in the law of proof of corruption. (3) How to maintain the validity of electronic evidence for the purposes of proof? Research method used is normative juridical approach, which is research based on secondary data, while the research specification used is descriptive analytical. The data source used consists of primary legal materials and secondary legal materials. The results concluded that: (1) Indonesia does not yet have a law governing electronic evidence that is generally applicable to all criminal acts. (2) The placement of electronic data as a means of evidence of instruction in the case of corruption is a form of dissertation and evidently has a weak position. (3) The validity of electronic evidence is determined through a forensic digital process with stages: maintained data integrity, the presence of competent persons, the preservation of chain of custody and compliance with regulations.

Keywords: electronic evidence; instructions; proof; corruption

\section{Abstrak}

Salah satu dampak negatif kemajuan teknologi digital adalah tumbuh kembangnya berbagai kejahatan dengan menggunakan sarana elektronik atau sarana lain yang berbasis pada komputerisasi, tidak terkecuali tindak pidana korupsi. Keadaan tersebut menuntut aparat penegak hukum dalam membuktikan perkara tindak pidana korupsi tidak hanya mengandalkan bukti-bukti konvensional, namun menggabungan metode teknologi digital elektronik sehingga melahirkan alat bukti elektronik. Persoalan mendasar terkait dengan hal ini di Indonesia yaitu: (1) Bagaimana pengaturan alat bukti elektronik di dalam hukum Indonesia (2) Bagaimana kedudukan alat bukti elektronik di dalam hukum pembuktian tindak pidana korupsi. (3) Bagaimana menjaga validitas alat bukti elektronik untuk kepentingan pembuktian? Metode Penelitian yang digunakan adalah pendekatan yuridis normatif, yaitu penelitian yang didasarkan pada data sekunder, sedangkan spesifikasi penelitian yang digunakan berupa deskriptif analitis. Sumber data yang digunakan

Supardi (2021) Prediksi Harga Mobil Bekas dengan Machine Learning. Syntax Literate. 6(5) http://dx.doi.org/10.36418/syntax-literate.v6i5.2724

2548-1398

Ridwan Institute 
terdiri dari bahan hukum primer dan bahan hukum sekunder. Hasil penelitian berkesimpulan bahwa: (1) Indonesia belum memiliki undang-undang yang mengatur alat bukti elektronik yang berlaku umum untuk semua tindak pidana. (2) Penempatan data elektronik sebagai alat bukti petunjuk dalam perkara tindak pidana korupsi merupakan bentuk diskrimansi dan secara pembuktian memiliki kedudukan yang lemah. (3) Validitas alat bukti elektronik ditentukan melalui proses digital forensik dengan tahapan: terpeliharanya integritas data, adanya orang yang kompeten, terpeliharanya chain of custody dan kepatuhan terhadap peraturan.

Kata Kunci: alat bukti elektronik; petunjuk; pembuktian; korupsi

\section{Pendahuluan}

Seiring dengan kemajuan dan perkembangan ilmu pengetahuan dan teknologi dalam masyarakat, berlaku pula bagi perkembangan kejahatan. Kejahatan dilakukan memanfaatkan dan menggunakan peluang yang disediakan oleh kemudahan instrumen teknologi canggih, tidak lagi dengan cara-cara tradisional. Kejahatan yang demikian itu merupakan kejahatan berdimensi baru. Istilah ini untuk menunjukkan suatu kejahatan yang berhubungan perkembangan masyarakat di bidang perekonomian dalam masyarakat industri, yang pelakunya terdiri dari golongan mampu, intelek, terorganisasi (termasuk dalam white collar crime). Mobilitas kejahatan tinggi dilakukan tidak hanya di suatu wilayah, melainkan antar wilayah, bahkan menerobos batas regional, transnasional modus-operandinya menggunakan peralatan canggih, memanfaatkan peluang kelemahan sistem hukum, sistem manajemen (Kunarto, 1991).

Meningkatnya tingkat kejahatan yang beririsan dengan pengembangan pengetahuan dan teknologi, dengan sendirinya membawa dampak kompleksitas modus operandi yang digunakan oleh para pelaku kejahatan termasuk kejahatan/ tindak pidana korupsi. Dampaknya, penindakan terhadap tindak pidana korupsi tidak dapat dilakukan hanya dengan cara-cara konvensional. Aparat penegak hukum harus memahami dan memanfaatkan jejak-jejak digital dan elektronik dalam pengungkapan dan pembuktian tindak pidana korupsi dengan sarana teknologi digital elektronik. Terminologi jejakjejak digital elektronik tersebut dikenal dengan sebutan "alat bukti elektronik atau sering disebut bukti elektronik".

Kitab Undang-Undang Hukum Acara Pidana (KUHAP) tidak mengenal alat bukti elektronik. Alat bukti yang dikenal dalam Pasal 184 ayat (1) KUHAP adalah keterangan saksi, keterangan ahli, surat, keterangan terdakwa dan petunjuk. Jejak digital yang diangkat menjadi formulasi alat bukti dimulai dengan diundangkannya UndangUndang (UU) Nomor 31 Tahun 1999 tentang Pemberantasan Tindak Pidana Korupsi Korupsi sebagaimana diubah dengan UU Nomor 20 Tahun 2001 tentang Perubahan UU Nomor 31 Tahun 1999 (selanjutnya disebut UUTPK). Pasal 26A UUTPK mengangkat jejak digital elektronik menjadi alat bukti "petunjuk", dengan rumusan sebagai berikut:

"Alat bukti yang sah dalam bentuk petunjuk sebagaimana dimaksud dalam Pasal 188 ayat (2) Undang-undang Nomor 8 Tahun 1981 tentang Hukum Acara Pidana, khusus untuk tindak pidana korupsi juga dapat diperoleh dari: 
a. alat bukti lain yang berupa informasi yang diucapkan, dikirim, diterima, atau disimpan secara elektronik dengan alat optik atau yang serupa dengan itu; dan

b. dokumen, yakni setiap rekaman data atau informasi yang dapat dilihat, dibaca, dan atau didengar yang dapat dikeluarkan dengan atau tanpa bantuan suatu sarana, baik yang tertuang di atas kertas, benda fisik apapun selain kertas, maupun yang terekam secara elektronik, yang berupa tulisan, suara, gambar, peta, rancangan, foto, huruf, tanda, angka, atau perforasi yang memiliki makna."

Undang-Undang Nomor 8 Tahun 2010 tentang Pencegahan dan Pemberantasan Tindak Pidana Pencucian Uang (selanjutnya disebut UUTPPU), dalam Pasal 73 menempatkan alat bukti digital elektronik yang disebut sebagai "alat bukti lain" selain yang diatur di dalam KUHAP berupa informasi yang diucapkan, dikirimkan, diterima, atau disimpan secara elektronik dengan alat optik atau alat yang serupa optik dan dokumen. Artinya UUTPPU menempatkan bukti digital sebagai alat bukti mandiri, bukan dilekatkan sebagai "alat bukti petunjuk" seperti dalam UUTPK. Redaksi yang hampir sama dengan UUTPPU yang menempatkan alat bukti elektronik sebagai alat bukti mandiri, ada di UU Nomor 11 Tahun 2008 tentang Informasi dan Transaksi Elektronik (selanjutnya disebut UUITE) dan beberapa undang-undang lain seperti UU Nomor 35 Tahun 2009 tentang Narkotika (Pasal 86), UU Nomor 1 Tahun 2007 tentang Pemberantasan Tindak Pidana Perdagangan Orang (Pasal 20) dan UU Nomor 9 Tahun 2013 tentang Pencegahan dan Pemberantasan Tindak Pidana Terorisme (Pasal 38).

Bukti elektronik pada dasarnya adalah informasi atau dokumen, atau dapat disebut secara umum "data", bukan alat. Data ini sifatnya "mirroring" atau copy dari perangkat. Data inilah yang digunakan sebagai alat bukti dalam pengungkapan dan pembuktian perkara pidana sejak penyidikan hingga di persidangan. KUHAP menentukan jenis alat bukti secara secara limitatif, sedangkan undang-undang khusus lainnya menambahkan "data" sebagai jenis alat bukti tambahan yang ada di KUHAP. Namun anehnya di antara undang-undang khusus tersebut tidak terdapat kata sepakat dalam menempatkan data sebagai alat bukti, ada yang menjadikan sebagai alat bukti petunjuk dan ada yang sebagai alat bukti tersendiri (mandiri).

Tidak adanya perlakuan yang sama terhadap data dan tidak adanya kesatuan pengaturan mengenai alat bukti elektronik ini menimbulkan problematik hukum baik dalam tataran normatif maupun praktis, mengingat alat bukti petunjuk sebenarnya memiliki gradasi terendah dalam fungsinya sebagai alat pembuktian. Bahkan secara gamblang van Bemelen (Hamzah, 2008) mengatakan bahwa petunjuk itu sebenarnya bukanlah alat bukti. Untuk itu relevan sekali dilakukan penelitian dan pengkajian mengenai persoalan pengaturan dan kekuatan alat bukti elektronik.

\section{Metode Penelitian}

Metode penelitian yang digunakan dalam penulisan ini adalah pendekatan yuridis normatif dengan spesifikasi penelitian bersifat deskriptif analisis, yaitu metode penelitian dengan cara mengumpulkan data-data sesuai dengan data yang sebenarnya kemudian data-data tersebut disusun, diolah dan dianalisis untuk memberikan gambaran 
mengenai masalah yang ada (Dr, 2008). Data-data sekunder yang diperoleh akan disajikan dalam bentuk uraian yang disusun secara sistematis sebagai suatu rangkaian yang utuh sehingga metode yang digunakan dalam penulisan hukum ini adalah metode kualitatif. Artinya data yang diperoleh disusun secara sistematis dalam bentuk uraian atau penjelasan untuk menggambarkan hasil penelitian (Soekanto, 1986).

\section{Hasil dan Pembahasan}

\section{Pengaturan bukti elektronik}

Proses pidana menurut KUHAP umumnya dimulai dengan penemuan peristiwa pidana oleh penyelidik melalui proses yang disebut penyelidikan, walaupun menurut ketentuan Pasal 104 KUHAP tingkatan penyelidikan bukan merupakan keharusan (not obligation for the criminal process). Peristiwa tersebut kemudian akan diuji di tingkat penyidikan melalui bukti-bukti yang diperoleh penyidik.

Menurut Pasal 1 angka 2 KUHAP yang dimaksud dengan penyidikan adalah serangkaian tindakan penyidik dalam hal dan menurut cara yang diatur dalam undang-undang untuk mencari serta mengumpulkan bukti yang dengan bukti itu membuat terang tentang tindak pidana yang terjadi dan guna menemukan tersangkanya. Tidak terdapat penjelasan yang memadai terkait ukuran keadaan yang bagaimana sehingga penyidik dikatakan telah berhasil membuat terang tindak pidana dan menemukan tersangka. Merujuk ketentuan Pasal 183 KUHAP, syarat yang harus dipenuhi oleh hakim setidak-tidaknya didukung dengan dua alat bukti sah ditambah adanya keyakinan. Alat bukti sah ditentukan secara limitatif dalam Pasal 184 ayat (1) KUHAP, yang terdiri: 1) keterangan saksi, 2) keterangan ahli, 3) surat, 4 petunjuk dan 5) keterangan terdakwa. Sistem pembuktian seperti ini disebut pembuktian negatif (negative wettelijk) atau pembuktian menurut undang-undang secara negatif.

Negative wettelijk mirip dengan sistem pembuktian convicition in raisone. Hakim di dalam mengambil keputusan tentang salah atau tidaknya seorang terdakwa terikat oleh alat bukti yang ditentukan dalam undang-undang dan keyakinan hakim sendiri, sehingga dalam sistem negatif ada dua syarat untuk membutikan kesalahan terdakwa, yaitu wettelijk berdasarkan alat bukti yang ditentukan undang-undang dan negative sesuai keyakinan hakim (Sasangka \& Rosita, 2003). Prinsip pembuktian tersebut harus dipedomani oleh penyidik dan jaksa dalam proses pengumpulan alat bukti di penyidikan dan penentuan kelengkapan berkas perkara-perkara, sehingga ketika berkas perkara pidana dinyatakan lengkap telah memenuhi kriteria mininal dua alat bukti yang cukup dan keyakinan terbukti di persidangan nantinya.

Pengertian penyidikan dalam Pasal 1 angka 2 tidak mengenal istilah alat bukti tetapi "bukti", sementara dalam Pasal 184 ayat (1) jo Pasal 183 KUHAP memakai istilah alat bukti. Kamus Besar Bahasa Indonesia (KBBI) memberikan pengertian bukti adalah sesuatu yang menyatakan kebenaran suatu peristiwa, 
kebenarannya, saksi, tanda hal yang menjadi tanda perbuatan jahat (Indonesia, 2008).

Menurut M. Yahya Harahap, secara yuridis pembuktian adalah ketentuanketentuan yang berisi penggarisan dan pedoman tentang cara-cara yang dibenarkan undang-undang untuk membuktikan kesalahan yang didakwakan kepada terdakwa. Pembuktian juga merupakan ketentuan yang mengatur alat bukti yang dibenarkan undang-undang dan mengatur mengenai alat bukti yang boleh digunakan hakim guna membuktikan kesalahan terdakwa. Pengadilan tidak boleh sesuka hati dan semena-mena membuktikan kesalahan terdakwa (Harahap, 2012).

Subekti dan R. Tjitrosoedibjo mengartikan bukti sebagai sesuatu untuk meyakinkan akan kebenaran suatu dalil atau pendirian. Alat bukti, alat pembuktian, upaya pembuktian, bewisje middle adalah alat yang dipergunakan untuk membuktikan dalil-dalil suatu pihak dimuka pengadilan (Hamzah, 1986). Andi Hamzah mendefinisikan tentang bukti dan alat bukti, yaitu sesuatu untuk meyakinkan kebenaran suatu dalil, pendirian dan dakwaan. Alat bukti ialah upaya pembuktian melalui alai-alat yang diperkenankan untuk dipakai membuktikan dalil-dalil atau dalam perkara pidana dakwaan disidang pengadilan, misalnya keterangan terdakwa, kesaksian, keterangan ahli, surat, petunjuk, dan termasuk persangkaan dan sumpah (Hamzah, 1986).

Pegertian bukti dan alat bukti sebagaimana dimaksud dalam Pasal 1 angka 2 dan Pasal 184 KUHAP sering dipersamakan dalam menyebut "data" sebagai out put suatu proses digital forensik atas benda sitaan elektronik (perangkat elektronik) yang lazim disebut sebagai barang bukti (elektronik) dan turunannya. Barang bukti elektronik adalah perangkat elektronik diperoleh melalui proses penyitaan yang dalam bahasa Pasal 44 KUHAP disebut sebagai benda sitaan. Sedangkan data elektronik sifatnya "mirroring" atau copy dari perangkat dan data inilah yang digunakan sebagai alat bukti elektronik yang tampil dalam bentuk informasi elektronik ataupun dokumen elektronik.

Barang bukti bukan alat bukti tetapi barang bukti bisa menjadi alat bukti petunjuk apabila bersesuaian dengan alat bukti lain. Dalam sistem Common Law seperti di Amerika Serikat, pengaturan alat bukti elektronik berbeda dengan sistem di Indonesia. Alat bukti yang disebut sebagai forms of evidence dalam US Criminal Procedure Law ialah real evidence, documentary evidence, testimonial evidence dan judicial notice. Dalam system ini real evidence (barang bukti) merupakan alat bukti yang paling bernilai, sementara itu real evidence di Indonesia bukanlah alat bukti, sehingga alat bukti elektronik jelas berbeda dengan barang bukti elektronik.

Dengan demikian pengertian bukti dalam Pasal 1 angka 2 KUHAP terdiri dari alat bukti dan barang bukti, sehingga relevan untuk tidak mencampur adukkan pengertian bukti elektronik dan alat bukti elektronik. Pembedaan istilah ini penting, setidaknya didukung dengan tiga alasan: pertama KUHAP mengenal istilah bukti, alat bukti dan barang bukti (benda sitaan) dalam fungsi yang 
berbeda-beda, kedua berpijak dari pengertian penyidikan (mencari dan mengumpulkan bukti), hasil pekerjaan penyidik berupa berkas perkara berisi kumpulan fakta dengan dukungan dua hal yaitu alat bukti dan barang bukti. Ketiga pernyataan Penuntut Umum menyatakan kelengkapan formil/materiil berkas perkara dari penyidik, alat ukurnya minimum pembuktian, yaitu unsurunsur pasal yang disangkakan setidaknya didukung dengan dua alat bukti sah sebagaimana dimaksud dalam Pasal 183 jo 184 ayat (1) KUHAP dan adanya barang bukti yang mendukung hal tersebut. Oleh karena itu penyebutan istilah bukti elektronik harus dibedakan dengan alat bukti elektronik.

Alat bukti elektronik berisi data elektronik yang terdiri dari informasi elektronik ataupun dokumen elektronik. Informasi elektronik adalah satu atau sekumpulan data elektronik, termasuk tetapi tidak terbatas pada tulisan, suara, gambar, peta, rancangan, foto, Electronic Data Interchange (EDI), surat elektronik (electronic mail), telegram, teleks, telecopy atau sejenisnya, huruf, tanda, angka, kode akses, simbol, atau perforasi yang telah diolah yang memiliki arti atau dapat dipahami oleh orang yang mampu memahaminya. Dokumen elektronik adalah setiap informasi elektronik yang dibuat, diteruskan, dikirimkan, diterima, atau disimpan dalam bentuk analog, digital, elektromagnetik, optikal, atau sejenisnya, yang dapat dilihat, ditampilkan, dan/atau didengar melalui komputer atau sistem elektronik, termasuk tetapi tidak terbatas pada tulisan, suara, gambar, peta, rancangan, foto atau sejenisnya, huruf, tanda, angka, kode akses, simbol atau perforasi yang memiliki makna atau arti atau dapat dipahami oleh orang yang mampu memahaminya.

Secara khusus undang-undang yang berkaitan langsung dengan obyek data elektronik atau "data" yang lahir dari transaksi elektronik, diatur di dalam UUITE. Undang-undang ini mengatur setiap perbuatan yang berhubungan dengan transaksi elektronik, yaitu setiap perbuatan hukum yang dilakukan dengan menggunakan komputer, jaringan komputer, dan/atau media elektronik lainnya.

UUITE dimaksudkan untuk merespon perilaku masyarakat maupun peradaban manusia secara global akibat perkembangan teknologi informasi dan komunikasi telah pula menyebabkan hubungan dunia menjadi tanpa batas (borderless) dan menyebabkan perubahan sosial, ekonomi, dan budaya secara signifikan berlangsung demikian cepat. Situasi ini telah lahir suatu rezim hukum baru yang dikenal dengan hukum siber atau hukum telematika. Hukum siber atau cyber law, secara internasional digunakan untuk istilah hukum yang terkait dengan pemanfaatan teknologi informasi dan komunikasi. Demikian pula, hukum telematika yang merupakan perwujudan dari konvergensi hukum telekomunikasi, hukum media, dan hukum informatika.

Istilah lain yang juga digunakan adalah hukum teknologi informasi (law of information technology), hukum dunia maya (virtual world law), dan hukum mayantara. Istilah-istilah tersebut lahir mengingat kegiatan yang dilakukan melalui jaringan sistem komputer dan sistem komunikasi baik dalam lingkup lokal 
maupun global (internet) dengan memanfaatkan teknologi informasi berbasis sistem komputer yang merupakan sistem elektronik yang dapat dilihat secara virtual.

Permasalahan hukum yang seringkali dihadapi adalah penyampaian informasi, komunikasi, dan/atau transaksi secara elektronik, khususnya dalam hal pembuktian dan hal yang terkait dengan perbuatan hukum yang dilaksanakan melalui sistem elektronik. Perbuatan hukum tersebut acapkali mengganggu keseimbangan hak pribadi orang lain atau dengan kewajiban hukum pelaku sehingga dikriminalisi menjadi delik yang diatur di dalam Pasal 27 s/d 37 Jis Pasal 45 s/d 42 UUITE.

Namun demikian UUITE hanya berlaku bagi dirinya sendiri. UUITE tidak menyatukan pemahaman fungsi alat bukti elektronik yang tersebar di undangundang lainnya, yang masing-masing memberikan porsi atau kedudukan berbedabeda. Alat bukti elektronik yang dimaksud dalam UUITE hanya berlaku untuk pembuktian perbuatan hukum dalam arti tindak pidana yang diatur di dalam UUITE. Pasal 2 UUITE menegaskan bahwa undang-undang tersebut hanya berlaku untuk setiap orang yang melakukan perbuatan hukum sebagaimana diatur dalam UUITE sehingga segala ketentuan tentang alat bukti elektronik tidak berlaku bagi undang-undang lain termasuk UUTPK.

Perbuatan hukum ini harus dimaknai semua bentuk transaksi elektronik yang berdimensi hukum baik dalam arti negatif (tindak pidana) maupun positif. Transaksi elektronik adalah perbuatan hukum yang dilakukan dengan menggunakan komputer, jaringan komputer, dan/atau media elektronik lainnya. UUITE bertujuan agar pemanfaatan Teknologi Informasi (TI) dan transaksi elektronik dilaksanakan berdasarkan asas kepastian hukum, manfaat, kehatihatian, iktikad baik, dan kebebasan memilih teknologi atau netral teknologi. Untuk itu perlu diatur sisi keamanan, kepastian hukum dalam pemanfaatan teknologi informasi, media dan komunikasi agar dapat berkembang secara optimal. Setiap perbuatan yang memanfaatkan dan menggunakan sarana TI harus memenuhi kriteria dan ketentuan UUITE, dengan konsekuensi pelanggaran dikenai pidana dan berlaku alat bukti elektronik menurut UUITE.

Alat bukti elektronik mandiri menurut UUITE tidak berlaku untuk tindak pidana lain di luar UUITE meskipun kejahatan dilakukan dengan sarana elektronik. Menjadi problem besar ketika dihubungkan dengan kejahatan umum yang diatur di dalam Kitab Undang-Undang Hukum Pidana (KUHP) yang tidak mengenal alat bukti elektronik.

Perdebatan di pengadilan dalam pengajuan alat bukti elektronik sangat mungkin terjadi, terlebih dalam perkara tindak pidana umum. Penasehat Hukum menganggap alat bukti yang diajukan Penuntut Umum ilegal atau tidak sah. Ketidakseragaman perlakuan perundang-undangan terhadap data elektronik sebagai alat bukti semestinya bisa diakhiri apabila setiap undang-undang 
menempatkan status dan kualitas yang sama terhadap alat bukti elektronik di dalam pembuktian perkara pidana yang menggunakan data elektronik.

Solusi paling ideal melalui legislatif (DPR) dengan melakukan revisi Pasal 184 ayat (1) KUHAP, menambahkan data elektronik sebagai alat bukti sah yang dan mandiri sehingga alat bukti elektronik menjadi milik semua tindak pidana tanpa kecuali. Terlebih, perkembangan kejahatan yang menggunakan sarana digital elektronik dan kompleksitas kejahatan termasuk delik-delik yang diatur di dalam KUHP menuntut pengungkapan dan pembuktian yang mendasarkan pada alat bukti elektronik. Jalan keluar kedua memberikan perlakuan yang sama di setiap undang-undang atas data elektronik, dengan cara revisi undang-undang yang memberikan perlakuan berbeda seperti UUTPK.

Perbedaan perlakuan alat bukti elektronik sangat mempengaruhi cara kerja aparat penegak hukum, baik dari sudut pembuktian perkara pidana maupun perlindungan hak asasi terdakwa. Sudarto mengemukakan bahwa keseluruhan fungsi penegak hukum termasuk cara kerja pengadilan merupakan bagian dari arti kebijakan kriminal dalam arti luas (Barda Nawawi Arief, 2016). Menurut G. Peter Hoefnagels sebagaimana dikutip Barda Nawawi Arief, kebijakan kriminal as a science policy is par of longer policy, the law enforcement policy. The legislative and enforcement policy is turn part of social policy. Jadi cara kerja aparat penegak hukum dalam membuktikan perkara, kerja legislatif merupakan bagian integral kebijakan sosial menuju kesejahteraan sosial dan perlindungan masyarakat.

Cara kerja dalam penegakan hukum merupakan bagian kebijakan sosial dalam melindungi masyarakat. Keberhasilan penegakan hukum tidak terlepas dari hasil kerja legislatif. Upaya penegakan hukum yang baik akan lebih mudah apabila didasari pada undang-undang yang baik, inilah yang dinamakan implementasi kebijakan kriminal yang baik. Ketika tedapat ketidaksempurnaan undang-undang sudah semestinya dilakukan perbaikan melalui revisi, perubahan atau penggantian.

\section{Mengukur kekuatan data elektronik sebagai alat bukti petunjuk dalam perkara tindak pidana korupsi.}

Menurut ketentuan Pasal 188 ayat (1) KUHAP petunjuk adalah perbuatan, kejadian atau keadaan, yang karena persesuaiannya baik antara yang satu dengan yang lain, maupun dengan tindak pidananya itu sendiri menandakan bahwa telah terjadi suatu tindak pidana dan siapa pelakunya. Perbuatan, kejadian dan keadaan yang saling bersesuaian itu sesuai Pasal 188 ayat (2) KUHAP hanya dapat diperoleh dari alat bukti berupa keterangan saksi, surat dan keterangan terdakwa. Ini artinya alat bukti petunjuk sebenarnya bukan sebagai alat bukti yang mandiri karena keberadaannya harus digantungkan pada alat bukti lain.

Pasal 188 KUHAP memiliki kemiripan dengan ketentuan Pasal 310, Pasal 311 dan Pasal 312 HIR dengan sedikit perbedaan. Petunjuk menurut Pasal 311 HIR selain diperoleh dari keterangan saksi, surat dan keterangan terdakwa juga dapat diperoleh dari pemeriksaan dan penglihatan hakim sendiri, sehingga 
pembuktian yang didasarkan petunjuk di berbagai alat bukti tidak mungkin diperoleh oleh hakim tanpa menggunakan redenering atau suatu pemikiran tentang adanya persesuaian antara kenyataan satu dengan kenyataan lain atau dengan tindak pidananya sendiri (Lamintang, 1984). Jadi sifat petunjuk sebagai alat bukti tidak mandiri dan sangat bergantung pada pemikiran hakim. Oleh karena itu Andi Hamzah berpendapat petunjuk lebih pantas disebut sebagai alat bukti pengamatan hakim seperti hanya UU Nomor 1 Tahun 1950 yang telah menghapus alat bukti petunjuk atau sama dengan Nederland Strafvordering yang baru.

Lebih lanjut Andi Hamzah dengan menyetir pendapat A. Minkenhof dikatakan: "Di sini tercermin bahwa pada akhirnya persoalannya diserahkan kepada hakim. Dengan demikian, menjadi sama dengan pengamatan hakim sebagai alat bukti. Apa yang disebut pengamatan oleh hakim (eigen waarneming van de rechter) harus dilakukan selama sidang, apa yang telah dialami atau diketahui oleh hakim sebelumya tidak dapat dijadikan dasar pembuktian, kecuali kalau perbuatan atau peristiwa itu telah diketahui oleh umum". (Hamzah, 2005) Hal ini berbanding lurus dengan praktek penyidikan yang menampilkan produk berkas perkara, dimana alat bukti yang tersusun di dalam berkas perkara tidak satupun menyebutkan alat bukti petunjuk sebagaimana dimaksud dalam Pasal 188 ayat (1) KUHAP karena alat bukti petunjuk pada prinsipnya didasarkan pengamatan pada saat pembuktian.

Oleh karena itu sangat beralasan apabila dikatakan alat bukti petunjuk memiliki gradasi terendah dibandingkan dengan alat bukti lain. Bahkan van Bemelen megatakan "tetapi kesalahan utama ialah petunjuk dipandang sebagai suatu alat bukti padahal pada hakekatnya tidak ada" (Hamzah, 2015). Artinya, menurut van Bemelen petunjuk sebenarnya bukan merupakan alat bukti.

Hal tersebut di atas relevan dengan bunyi Pasal 188 ayat (3) KUHAP yang memberikan catatan khusus bahwa penilaian atas kekuatan alat bukti petunjuk dalam setiap keadaan tertentu dilakukan oleh hakim dengan arif dan bijaksana, setelah ia mengadakan pemeriksaan dengan penuh kecermatan dan keseksamaan berdasarkan hati nuraninya. Ketentuan ini seolah memberikan pesan, sebaikbaiknya pembuktian adalah dengan menggunakan alat bukti yang secara nalar obyektif tidak memerlukan pemikiran khusus untuk menganggapnya sebagai alat bukti (alat bukti mandiri). Intinya penggunaan alat bukti petunjuk sedapat mungkin diminimalisir dengan menggunakan alat bukti lain yang ukuran obyektifnya lebih jelas, seperti alat bukti keterangan saksi, keterangan terdakwa, surat dan keterangan ahli.

Pasal 5 ayat (1) dan (2) UUITE mengatakan bahwa data yang berupa informasi elektronik dan dokumen elektronik berikut hasil cetakannya merupakan "alat bukti hukum yang sah" sebagai perluasan alat bukti yang diatur di dalam Pasal 184 ayat (1) KUHAP. UUITE menempatkan data yang berisi informasi dan dokumen elektronik merupakan alat bukti mandiri yang tidak 
digantungkan pada alat bukti lain. Redaksi "alat bukti sah" sama dengan penyebutan yang diatur di dalam undang-undang lain di luar KUHAP seperti tindak pidana pencucian uang, narkotika, terorisme dan lain-lain yang menempatkan data elektronik sebagai alat bukti mandiri dan sempurna sebagai tambahan jenis alat bukti yang diatur di dalam Pasal 188 KUHAP. Hal berbeda dengan ketentuan Pasal 26A UUTPK yang menempatkan data elektronik sebagai sumber untuk mendapatkan petunjuk (sebagai alat bukti petunjuk).

Mengingat kedudukan, sifat dan kharakter alat petunjuk tersebut, maka penempatan alat bukti elektronik sebagai petunjuk dalam pembuktian perkara tindak pidana korupsi harus mengikuti sifat dan kharakter alat bukti petunjuk sebagaimana dimaksud di dalam KUHAP. Penggunaan alat bukti petunjuk di dalam khasanah pembuktian harus mengikuti tata cara yang sama layaknya alat bukti petunjuk, yaitu berdasarkan penilaian dan pengamatan di dalam sidang oleh hakim.

Tren yang berkembang dalam pembuktian perkara sulit terutama tindak pidana korupsi, alat bukti elektronik merupakan "pembunuh" (baca: alat bukti) handal untuk membuktikan perbuatan dan kesalahan terdakwa karena alat bukti elektronik mampu merekam kejadian ante factum seperti "apa adanya". Sebagai alat bukti handal, dengan mudah alat bukti elektronik mampu membentuk keyakinan terbuktinya perbuatan dan kesalahan terdakwa.

Alat bukti elektronik relatif sebagai alat bukti yang sulit dibantah baik oleh saksi maupun terdakwa. Bantahan yang sifatnya kebohongan secara gestur tubuh dan ketidaklogisan bantahan mudah diketahui sehingga tidak sulit melahirkan keyakinan mengenai kebenaran alat bukti elektronik. Terlebih lagi alat bukti elektronik dapat melahirkan alat bukti lain yaitu ahli, seperti ahli digital forensik yang membenarkan suara dan gambar saksi maupun terdakwa yang terekam di dalam alat bukti elektronik, seperti nampak dalam persidangan perkara tindak pidana korupsi (suap) dengan terdakwa Eddy Sindoro di Pengadilan Negeri Jakarta Pusat. Terdakwa membantah alat bukti rekaman suara hasil penyadapan yang diajukan oleh Penuntut Umum bahwa suara di dalam rekaman bukan suaranya. Ahli digital forensik Dhany Arifianto dari Institut Teknologi Surabaya (ITS) menerangkan suara di dalam rekaman tersebut identik dengan suara milik Eddy Sindoro.

Alat bukti elektronik merupakan alat bukti "apa adanya" (as it is), ditampilkan di dalam sidang dan sebagai informasi apa adanya, layaknya seorang saksi yang merekam dan menceriterakan kembali apa yang pernah dilihat, diketahui dan didengar sendiri. Ketika isi yang terurai dalam alat bukti elektronik tersebut bersesuaian dengan alat bukti lain (seperti saksi), maka semestinya alat bukti elektronik secara mandiri telah berfungsi sebagai alat bukti mandiri dan memenuhi kualifikasi dua alat bukti cukup, tidak lagi menjadi sumber alat bukti petunjuk yang harus diproses melalui pengamatan hakim. Merujuk pada Pasal 185 
ayat (6) KUHAP, maka alat bukti keterangan saksi dapat dikatakan telah bersesuaian dengan alat bukti elektronik, misalnya hasil sadapan.

Dengan demikian secara normatif dan teknis, penempatan alat bukti elektronik lebih tepat apabila diletakkan sebagai alat bukti lain yang sah di luar ketentuan Pasal 184 ayat (1) KUHAP, artinya alat bukti elektronik tidak disposisikan sebagai alat bukti petunjuk sebagaimana dalam UUTPK. Alih-alih sebagai mesin pembunuh, justeru alat bukti elektronik di UUTPK tidak menjadi alat bukti yang mandiri tetapi harus dilekatkan sebagai alat bukti petunjuk.

Ironisnya, secara teknis alat bukti elektronik sebagai petunjuk maupun sebagai alat bukti mandiri, tidak terdapat perbedaan substansial baik dalam "memperoleh maupuan menampilkan" di persidangan. Misalnya hasil intercept melalui media sosial atau sarana yang digunakan oleh orang untuk berinteraksi satu sama lain dengan cara menciptakan, berbagi, serta bertukar informasi dan gagasan dalam sebuah jaringan dan komunitas virtual. Penuntut Umum akan menunjukkan visualisasi percakapan, gambar atau tulisan tersebut di depan persidangan. Tidak ada perbedaan perlakuan di tataran teknis sehingga pembedaan dalam undang-undang menjadi sesuatu yang aneh, menyimpang dari konsep alat bukti petunjuk dan lebih jauh tentunya merugikan kepentingan terdakwa.

Selain itu alat bukti elektronik juga dapat diperoleh melalui proses pengolahan digital forensik atas benda sitaan elektronik (perangkat elektronik) sehingga diperoleh data elektronik atas benda sitaan/barang bukti elektronik, termasuk proses cloning atas data-data yang telah terhapus. Mekanisme penampilan keduanya dalam pembuktian di pengadilan tidak memiliki perbedaan, sehingga menempatkan keduanya dalam kualitas yang berbeda menjadi sesuatu yang tidak tepat.

Oleh karena itu penempatan kualitas berbeda terhadap alat bukti elektronik di dalam UUTPK menandakan sebagai kebijakan kriminal yang diskriminatif dibandingkan dengan undang-undang di luar KUHP lainnya. Karena itu penempatan kualifikasi data elektronik sebagai alat bukti petunjuk di dalam UUTPK perlu ditinjau ulang.

\section{Validitas alat bukti elektronik.}

Di Indonesia belum terdapat peraturan khusus terkait alat bukti elektronik yang berlaku umum (untuk semua tindak pidana). UUITE merupakan ketentuan khusus yang mengatur aktifitas bidang elektronik yang di dalamnya juga mengatur alat bukti elektronik, tetapi terbatas berlaku pada perbuatan hukum yang diatur di dalam UUITE. Menurut Pasal 5 ayat (3) jo Pasal 6 UUITE Informasi elektronik dan/atau dokumen elektronik dinyatakan sah apabila menggunakan sistem elektronik yang memenuhi persyaratan minimum sebagai berikut:

a. dapat menampilkan kembali informasi elektronik dan/atau dokumen elektronik secara utuh sesuai dengan masa retensi yang ditetapkan dengan peraturan perundang-undangan; 
b. dapat melindungi ketersediaan, keutuhan, keotentikan, kerahasiaan, dan keteraksesan informasi elektronik dalam penyelenggaraan sistem elektronik tersebut;

c. dapat beroperasi sesuai dengan prosedur atau petunjuk dalam penyelenggaraan sistem elektronik tersebut;

d. dilengkapi dengan prosedur atau petunjuk yang diumumkan dengan bahasa, informasi, atau simbol yang dapat dipahami oleh pihak yang bersangkutan dengan penyelenggaraan sistem elektronik tersebut; dan

e. memiliki mekanisme yang berkelanjutan untuk menjaga kebaruan, kejelasan, dan kebertanggungjawaban prosedur atau petunjuk.

Suatu informasi elektronik dan/atau dokumen elektronik dapat menjadi alat bukti yang sah di persidangan harus harus didasarkan sertifikasi, baik mengenai subyek maupun sistemnya. Syarat-syarat mengenai penyelenggara sertifikasi dan penyelenggaraan sistem elektronik diatur dalam Pasal 13 sampai dengan Pasal 16 UUITE. Proses dan pengelolaan (processing and treatment) atas informasi elektronik dan/atau dokumen elektronik sehingga menjadi alat bukti memerlukan ilmu keahlian khusus yang disebut sebagai digital forensik (digital forensic).

Menurut Prayudi, dkk digital forensik adalah penggunaan ilmu dan metode untuk menemukan, mengumpulkan, mengamankan, menganalisis, menginterpretasi dan mempresentasikan barang bukti digital dalam rangka kepentingan rekontruksi kejadian serta memastikan keabsahan pada proses peradilan (Prayudi \& Ashari, 2015). Kebande, dkk. menambahkan:

"digital forensic can be used to obtain digital evidence for use in a court of law during criminal or civil proceedings. This involves using scientifically proven methods to acquire, examine, identify, analyse and present digital evidence from digital sources that may have reliable information to prove or disprove a hypothesis about a security incident" (Kebande, Karie, \& Venter, 2016).

Demikian juga Digital Forensic Research Workshop (DFRWS) yang berpusat di Utica, NY menyatakan bahwa:

"digital forensic sciensce as "the use of scientifically derived and proven methods toward the preservation, collection, validation, identification, analysis, interpretation, documentation and presentation of digital evidence derived from digital sources for the purpose of facilitating or furthering the reconstruction of events found to be criminal, or helping to anticipate unauthorized actions shown to be disruptive to planned operations" (Kebande et al., 2016).

Dalam digital forensic terdapat tiga entitas yang memiliki peran yang sangat penting, yaitu manusia sebagai aktor yang melakukan aktivitas, digital evidence sebagai objek dan aset vital, dan process sebagai pedoman yang harus diikuti sepanjang proses investigasi digital forensic berlangsung. Pedoman dalam pelaksanaan investigasi tersebut menggunakan metode ilmiah, artinya dalam setiap tahapan atau langkah yang dilakukan oleh tim investigasi ataupun lembaga 
hukum harus menjunjung tinggi kaidah metode ilmiah. Dengan berpedoman pada karakteristik metode ilmiah, maka proses dalam bidang digital forensic harus mengacu pada langkah-langkah prosedural dan terstruktur. Dalam prosesnya dikenal dengan digital forensic investigation. Digital forensic investigation diterapkan setiap penyelidikan terhadap barang bukti digital sebagai hasil dari suatu kejadian, untuk menentukan kejadian itu termasuk sebagai kegiatan kriminal atau bukan (Sudirman, 2019).

Perolehan dan pengelolaan data elektronik penting dalam rangka menjamin obyektifitas dan validitas alat bukti elektronik. Secara khusus Indonesia belum memiliki aturan yang khusus dan berlaku umum mengenai hal ini. Praktek selama ini disandarkan pada standar ilmiah yang berlaku secara internasional. Secara internasional, prinsip pokok dalam penanganan alat bukti elektronik meliputi: terpeliharanya integritas data, adanya orang yang kompeten, terpeliharanya chain of custody dan kepatuhan terhadap peraturan.

Prinsip pokok tersebut dapat diterjemahkan ke dalam empat prinsip dasar digital forensik sebagaimana ditetapkan oleh Asosiasi Pimpinan Kepolisian Negara Inggris (Association of Chief Police Officers /ACPO), yaitu:

1. No action taken by law enforcement agencies or their agents should change data held on a computer or storage media which may subsequently be relied upon in court. Sebuah lembaga penegak hukum dan/atau petugasnya dilarang mengubah data digital yang tersimpan dalam suatu media penyimpanan elektronik yang selanjutnya akan dibawa dan dipertanggungjawabkan di pengadilan.

2. In exceptional circumstances, where a person finds it necessary to access original data held on a computer or on storage media, that person must be competent to do so and be able to give evidence explaining the relevance and the implications of their actions. Untuk seseorang yang merasa perlu untuk mengakses data-data digital yang tersimpan di media penyimpanan barang bukti, maka orang tersebut harus benar-benar jelas kompetensinya dan dapat menjelaskan relevansi dan implikasi dari tindakan-tindakan yang ia lakukan selama pemeriksaan dan analisis barang bukti tersebut.

3. An audit trail or other record of all processes applied to computer based electronic evidence should be created and preserved. An independent third party should be able to examine those processes and achieve the same result. Seharusnya ada catatan teknis dan praktis terhadap langkah-langkah yang diterapkan terhadap media penyimpanan barang bukti selama pemeriksaan dan analisis berlangsung, sehingga ketika barang bukti tersebut diperiksa oleh pihak ketiga maka seharusnya pihak ketiga tersebut akan mendapatkan hasil yang sama dengan hasil yang telah dilakukan oleh investigator/analis forensik sebelumnya.

4. The person in charge of the investigation (the case officer) has overall responsibility for ensuring that the law and these principles are adhered to. 
Seseorang yang bertanggung jawab terhadap investigasi kasus maupun pemeriksaan dan analisis barang bukti elektronik harus dapat memastikan bahwa proses yang berlangsung sesuai dengan hukum yang berlaku dan prinsip-prinsip dasar sebelumnya (prinsip 1,2, dan 3) dapat diaplikasikan dengan baik.

Berdasarkan hal tersebut di atas, barang bukti elektronik ataupun data elektronik untuk dapat menjadi suatu alat bukti elektronik harus melalui rangkaian proses berstandar ilmiah. Hal ini bertujuan agar terjaga proses hukum yang fair dan tidak melanggar hak asasi baik tersangka/terdakwa maupun sumber darimana data elektronik diperoleh dalam kerangka pembuktian perkara pidana (due process of law).

\section{Kesimpulan}

Alat bukti elektronik pada prinsipnya copying atau mirroring isi dari benda elektronik. Indonesia belum memiliki undang-undang yang mengatur kedudukan dan kualitas alat bukti elektronik yang berlaku secara umum (semua jenis tindak pidana), namun tersebar di berbagai undang-undang dengan menempatkan kualitas dan kedudukan yang berbeda-beda.

Alat bukti petunjuk memiliki gradasi kualitas terendah sebagai alat bukti. Penempatan data elektronik sebagai alat bukti petunjuk dalam perkara tindak pidana korupsi atau UUTPK merupakan bentuk diskrimansi yang tidak mencerminkan bentuk kebijakan kriminal yang baik.

Alat bukti elektronik harus memiliki validitas pembuktian. Validitas alat bukti elektronik ditentukan melalui proses digital forensik dengan tahapan: terpeliharanya integritas data, adanya orang yang kompeten, terpeliharanya chain of custody dan kepatuhan terhadap peraturan. 


\section{BIBLIOGRAFI}

Barda Nawawi Arief, S. H. (2016). Bunga rampai kebijakan hukum pidana. Prenada Media. Google Scholar

Dr, P. (2008). Sugiyono, Metode Penelitian Kuantitatif Kualitatif dan R\&D. CV. Alfabeta, Bandung. Google Scholar

Hamzah, Andi. (1986). Kamus Hukum (p. 99). p. 99. Jakarta, Ghalia Indonesia. Google Scholar

Hamzah, Andi. (2005). Pengantar Hukum Acara Pidana di Indonesia (pp. 254-255). pp. 254-255. Sinar Grafika, Jakarta. Google Scholar

Hamzah, Andi. (2008). Hukum Acara Pidana Indonesia, Sinar Grafika. Jakarta. Google Scholar

Hamzah, Andi. (2015). Delik-delik tertentu (Speciale Delicten) di dalam KUHP. Sinar Grafika. Google Scholar

Harahap, M. Yahya. (2012). Pembahasan Permasalahan dan Penerapan KUHAP, Pemeriksaan Sidang Pengadilan, Banding dan Peninjauan Kembali. Edisi Kedua. Cetakan Pertama. Jakarta: Sinar Grafika. Google Scholar

Indonesia, Kamus Besar Bahasa. (2008). Departemen Pendidikan dan Kebudayaan (p. 133). p. 133. Jakarta: Balai Pustaka.

Kebande, Victor R., Karie, Nickson M., \& Venter, H. S. (2016). A generic Digital Forensic Readiness model for BYOD using honeypot technology. 2016 IST-Africa Week Conference, 1-12. IEEE. Google Scholar

Kunarto. (1991). Gelagat Perkembangan Kejahatandan Kebijakan Penanggulangannya, Makalah Seminar KRIMINOLOGI VIII. Fakultas Hukum Universitas Diponegoro, Semarang. Google Scholar

Lamintang, P. A. F. (1984). Kitab Undang-Undang Hukum Acara Pidana dengan pembahasan secara yuridis menurut yurisprudensi dan ilmlu pengetahuan hukum pidana. Sinar Baru. Google Scholar

Prayudi, Yudi, \& Ashari, Ahmad. (2015). A Study on Secure Communication for Digital Forensics Environment. Int. J. Sci. Eng. Res, 6(1), 1036-1043. Google Scholar

Sasangka, Hari, \& Rosita, Lily. (2003). Hukum pembuktian dalam perkara pidana: untuk mahasiswa dan praktisi. Mandar Maju. Google Scholar

Soekanto, Soerjono. (1986). Pengantar Penelitian Hukum, Jakarta. Penerbit Universitas Indonesia. 
Supardi

Sudirman, Asep. (2019). Kerangka Kerja Digital Forensic Readiness pada Sebuah Organisasi (Studi Kasus: PT Waditra Reka Cipta Bandung). Universitas Islam Indonesia. Google Scholar

Copyright holder :

Supardi (2021)

First publication right :

Journal Syntax Literate

This article is licensed under:

(c) $(7) \ominus$ 